\title{
The Review of Recent Policies of Teachers' Education Fund Investment in Some Countries and the Implication
}

\author{
Rong MO'${ }^{1}$, Bai-cai SUN ${ }^{1}$, Jie LIU² and Zun-li MO' \\ ${ }^{1}$ Northwest Normal University, Lanzhou, China, 730070 \\ ${ }^{2}$ The Institute of Arts, Lanzhou City College, Lanzhou, China, 730070 \\ ${ }^{*}$ Corresponding author: Rong MO
}

Keywords: Teachers' education funds investment policies, Teachers' quality, Australia, New Zealand, The United States, South Africa.

\begin{abstract}
To provide the excellent school education has become an important means of building a lifelong learning society in the world, and the key to improve the quality of school education is the construction of teachers. Australia, New Zealand, the United States and South Africa carried out the stereo and multilayer financial investment policies to enhance teachers' quality, such as setting up the teachers' education special funds on teachers' training in math, science, helping effective teachers' development and professional development. In the post $4 \%$ era, we should deepen the reform of teacher education and take the road of teachers' education development; make the construction of teachers' team as the key areas for education expenditures; carry out the leading and exemplary role in the central budget; improve the sharing funding of central and local fiscal in the primary and secondary school teachers; enhance the quality of education in public school.
\end{abstract}

\section{Introduction}

Australia, New Zealand, the United States and South Africa increased the fund investment, established the special funds to promote the teachers' status to strengthen the construction of teachers team in recent years. United States Department of Education Secretary Arne Duncan put the teachers' status to an unprecedented height in public speech: "The quality of education is more important than the quality of teachers." On the teachers' incentive mechanism, Australia, New Zealand, the United States and South Africa governments invest a large amount of money on teachers training for primary and secondary school teachers every year, and offering teacher training course to further improve the level of teachers' ability of scientific research and teaching, considered good education is the foundation of a good education system by qualified teachers.

\section{The Present Professional Status of Primary and Middle School Teachers in Some} Countries

Australia state or territory is responsible for teachers' education. Teacher is a kind of civil service profession in Australia and teachers' social status is generally lower in primary and secondary schools than the professors in universities, especially some professors do some research work for scientific research institute and government. In 2011, Australia average annual salary was $\$ 71,600$, starting salaries for primary and middle school teachers in New South Wales is $\$ 46,000$ per year, teachers with senior titles with an average salary of $\$ 60,000$. The average salary of university principles is $\$ 100,000$. Victoria University 
teachers' starting salary is $\$ 57,000$ per year, while University professors with an average annual salary of $\$ 84,000$, university principals with an average salary of $\$ 92,000$. The highest wage level is usually less than the starting salaries of teachers of 1.4 to 1.5 times, while the highest wages in the other OECD can reach more than twice times compared to starting salary[1].These data indicates that Australia teachers' average salary level is not high. However, teachers in Australia is stable and it has subsidies in remote areas, shorter working time, teachers remain to be favored career choice for graduates of Australia.

In New Zealand, the government carries out many reforms and establishes a sound assurance system of early childhood teacher quality, which including teacher education, policies and systems, financial support, professional standards and qualifications. "Initial Teacher Programme" and "Induction and Mentoring Programme" in New Zealand are important teachers education programmes. New Zealand mainly put some fund support on early childhood teachers, and strongly supporting the establishment of assurance system, establishing the education funding link, promoting teacher quality improvement and so on.

United States teachers' occupational barriers and salaries are relatively low and unable to attract or retain outstanding graduates of the university. Above problems cause United States the teacher retention rate is lower, according to the survey of United States NationalEducation Association (National Education Association), nearly 1/5 teachers left school within 3 years in the whole country after they became teachers. United States National Center for education statistics (NCES) data showed that close to 1/3 new teachers left school in their first three years, turnover in the first five-year term even up to $50 \%$, it needs 2.4 million new teachers in public schools across the United States in 2012. Besides, the wastage rate is higher in first year teachers in weak school and the rate is as high as $61.9 \%$ [2]. United States need to upgrade the quality of teacher training, and teachers' professional preparation and development is not sufficient.

On the teachers' income distribution, South Africa annual wage income for teachers is equal to nurses in 2003, and these three occupational wage is almost the average level for all industries. According to statistics, the wastage rate of teachers in South Africa up to 5\%-5.5\% each year, approximately 17,000-20,000 teachers left the work. This indicates that South Africa needs to increase about 20,000-30,000 teachers each year, but teachers' education training institution only can train 5,000 to 7,000 teachers per year[3].Besides, gender imbalance among teachers existed in primary and secondary school, according to Shisana's statistics, in 2004, two-thirds teachers in primary and secondary school are women, other primary school's female teachers in other provinces up to $75 \%$ expect Limpopo Province accounted for $67 \%$. But the sex ratio of teachers in secondary school is almost balanced, for men and women respectively $47 \%$ and $53 \%$ [3].

\section{Establishing the Special Funds and Actively Promoting the Reform of Teachers education}

In order to improve the professional quality and occupational status of primary and middle school teachers, further to improve the quality of education, and Australia, New Zealand, the United States and South Africa actively promoted reforms of teachers' education, increased funding investment, and implemented a series of projects. 


\section{The Special Funding Projects for Teachers' Education in Australia}

“Australian Government Quality Teacher Program"(AGQTP). "Australian Government Quality Teacher Program"(AGQTP)is the competitive grants that provided by the Federal Ministry of education from 2000 to now. Up to 2004-2005, the government invested \$82.4 million and provides professional learning opportunities for 240,000 teachers. The purpose is to equip teachers with the skills and knowledge needed for the teaching in the 21 st century, provide the professional learning need in high priority and improve the professional standing of teachers in the school and leaders. In 2011-2013, the fund is up to \$ 22.5 million[4]. The provision of AGQTP professional development activities should contribute to the following outcomes: (1) effectively training principals, teachers and school leaders for their roles and school environment; (2) developing teachers and school leaders to enhance their skills and knowledge throughout their careers; (3) equipping teachers with skills to assist young people to meet basic literacy and numeracy standards and improve overall levels of literacy and numeracy; (4) support for the implementation of the National Teacher Professional Standards; (5) support for the implementation of the Australian Curriculum; (5) ability of teachers and schools leaders to effectively implement student well-being in schools, including managing bullying[4].

"Smarter Schools Teacher Quality National Partnership". "Smarter Schools Teacher Quality National Partnership" is set up in 2008, and the Council of Australian Governments signed the "Smarter Schools-Improving Teachers Quality National Partnership Agreement" with other States. The project period is up to 5 years and it plans to invest 550 million Australian dollars to Australia for education system reform, improve the overall quality of all Australian primary and secondary school teachers and principals to ensure Australia education as a leadership level. This project includes helping students, supporting the development of teachers and school leaders and improving students' ability of reading, writing and math[5]. In the promoting of this project, some States made some relevant teaching training projects, for example, capital region set up a teachers' Association for quality (Teacher Quality Institute) as the specialized registration in the capital city; Western Australia Department of education has launched a series of teachers' quality improvement projects, including initial teacher training, leadership strategies of education, teachers' professional skills upgrading programs.

\section{The special funding projects for teachers' education in New Zealand}

In recent years, New Zealand's teachers' education investment policies are mainly include "ECE Funding Subsidy", “Early Children Education Service Teacher Education Grant", "Support Grant for Provisionally Registered", "Annual Top-Up for Isolated Services", "20 Hours Free Programme", "Incentive Grants", "Equity Funding"and so on[6]. "Equity Funding" invested $\$ 30$ million for 4 years on teachers' training. These policies focused on pre-school education fund investment and improve teachers' quality. Besides, New Zealand government launched some acts and laws to support the development of education, such as "Education Act 1989", 'Licensing Criteria for Early Children Education and Care Centers 2008", "Education (Early Childhood Services) Regulations 2008)", "Pathways to the Future", and 'Five- year Plan (2007-2012)", which indicated the teachers' training and presented the importance on teachers' education and fund investment, and increase the fund support. In addition, New Zealand carried on new eduaction fund system from 2005 and All-day services had qualitify to get more fund support. 


\section{The special funding projects for teachers' education in the United States}

The special funding projects for teachers' education in United States are divided into general grants and competitive grants. The former is used to guarantee the sustainability of the reform of teachers' education; the latter is to determine the allocation items according to the actual needs of the regions and the information provided by the applicant.

"Improving Teacher Quality State Grants". 'Improving Teacher Quality State Grants" is the general grants that provided by the Federal Ministry of education for the States projects in 2006. In 2013, the disbursement of funds reaches $\$ 2.338$ billion. By 2014, the disbursement of fund is up to $\$ 2.35$ billion[7]. The purpose of the program is to increase academic achievement by improving teacher and principal quality. This program is carried out by: increasing the number of highly qualified teachers in classrooms; increasing the number of highly qualified principals and assistant principals in schools; and increasing the effectiveness of teachers and principals by holding LEAs and schools accountable for improvements in student academic achievement[8].

"Teacher Quality Enhancement Grants". "Teacher Quality Enhancement Grants" is the competitive grants that provided by the Federal Ministry of education for the States projects in 2000, the funds supporting has declined year by year. The Office of Postsecondary Education administered TQE grants prior to 2009. The grants awarded in OPE consisted of three discretionary grant programs: State, Partnership and Recruitment Grants. Funds were awarded to institutions of higher education, state education agencies, or local agencies. These institutions in turn awarded scholarships to students who promised to teach in a high-need school district. In 2000, the funds are \$ 98 million, in 2009, the average special funds are $\$ 728,000$, and it has not been disbursed from 2010 and this kind of fund should apply by the education institution or local school districts volunteered[9]. The purpose of this grant is to improve teachers' training programs across the United States, give support to primary and secondary schools and higher education institutions in establishing partnerships to improve the quality of teacher training, provides internship opportunities for teachers, the implementation of reforms of teacher recruitmen.

"Teacher Incentive Fund". "Teacher Incentive Fund" is the competitive grants that provided by the Federal Ministry of education for the States projects in 2006. This program provides funding for projects that develop and implement performance-based teacher and principal compensation systems in high-need schools. The purpose of the TIF program is to support the use of performance-based compensation, and other human capital strategies that enhance and sustain performance-based compensation, in order to increase students' access to effective educators in high-need schools, and to expand the array of promising approaches that can help these educators and other personnel succeed[10].In 2008, the funds were $\$ 97.27$ million; in 2009, the funds were up to \$200 million after the enactment of "American Recovery and Reinvestment Act (ARRA)"; in 2010, the fund had reached\$ 400 million. In 2011, the fund was \$ 399 million; in 2012, the fund was \$ 299 million. In 2013, the continued fund was $\$ 284$ million; in 2014, the fund was up to $\$ 289$ million.

"Transition to Teaching". "Transition to teaching" is the competitive grants that set up in 2009 , the purpose is to Recruit and retain highly qualified mid-career professionals (including highly qualified paraprofessionals) and recent graduates of Institutions of Higher Education (IHEs), as teachers in high-need schools, including recruiting teachers through alternative routes to teacher certification[11].In 2009, 14 institutions or organizations successfully applied for the funds and allocated a total of \$ 43.7 million. In 2010, the Fund reached \$ 41.26 million; 
in 2011 amounts was up to $\$ 41.12$ million; in 2012, the fund reached $\$ 26.05$ million; in 2013, the fund was $\$ 18.27$ million; in 2014, the fund was $\$ 13.64$ million; in 2015 , the fund is $\$ 13.63$ million[12].

"Teacher Quality and Quality of Other Service Providers for Students with Disabilities". "Teacher Quality and Quality of Other Service Providers for Students with Disabilities" is the competitive grant that set up in 2007, and the project period was up to 5 years. In 2007, the fund was 1.2 million; in 2009, the fund was 1.31 million[13]. The purpose is to identify effective strategies for preparing future teachers and other service providers of students with disabilities, or for improving the performance of current teachers and service providers of students with disabilities, in ways that increase student learning and school achievement.

"RESPECT". "RESPECT" is the competitive grant that set up in 2012 and the whole investment fund was 5 billion dollars. The purpose is to help States and communities in all stages of the reform of teacher professional development, and attract the excellent talent in the education industry, and help them to succeed. The project will plan to recruit 1 million qualified teachers in the 4-6 years. This project's long-term goal is to make teachers not only the most important professions in United States, but became the most respected profession.

\section{The Special Funding Projects for Teachers' Education in South Africa}

"National Policy Framework for Teacher Education and Development (2007)" aimed at develop the teachers quality management, professional development and fund support. South Africa government devoted to teachers' education investment in the way that design different teaching training models, such as " $4+0$ " model, "consecutive model", " $3+1$ " model, " $4+1$ " model, 'Improving teachers' qualification model'[14].And government provide the certificates after teachers finished the training and study, such as "ACE", "NPDE", and the teachers can continue to study and get the Master degree, such as B Ed Hons, MEd, DEd. South Africa made the law and policies to promote teachers' education are the feature and emphasized the education justice, established the standards system, pedagogical and content knowledge training, evaluate the effects of training.

\section{The Implication to China}

On the background of the society of knowledge economy, providing the excellent school education has become an important means of building a lifelong learning society in the world, and the key to improve the quality of school education is the construction of teachers. In order to improve the quality of teachers and to ensure the quality of education, the governments of United States and Australia attach great importance to teachers' education reform; the two Governments have increased funding investment. Through the establishment of special funds of the central government, it brings out the reform of teacher education in each State, increasing training opportunities for teachers and improving teachers' salary and career status. According to the special funding investment of teachers' education in the United States and Australia, we can draw the following implications to China:

Firstly, China should deepen the reform of teacher education, take the road of education development, investing more fund on the construction of teachers. In 2012, the public education funds of China has reached $4 \%$ of GDP, the development of education come into a new stage of improving education quality and promoting the education equity. In the post $4 \%$ era, teachers' work should be regarded as priority protection in key areas of the education 
expenditure, carrying out the leading and exemplary role of central finance, and establishing a perfect central and local fund sharing mechanism.Secondly, the special funds investment for teachers' education or primary and secondary schools in the United States and Australia covering a wide range and has strong policy continuity. Teachers' education special investment plans in both countries are many-dimensional and multidimensional financial investment policies that to enhance teachers' quality. It built the professional development platform for primary and secondary school teachers and has significant influence on Chinese teachers' education investment policies. China should strengthen the macro-control role of government in the allocation of educational resources for teachers, design multi-level, diversified special projects of teachers' education. Third, we should further improve the transfer payment system and the sharing funding of central and local fiscal in the primary and secondary school teachers, strengthening principal's ability of weak schools, promoting professional development of teachers, increasing teacher training opportunities and other aspects to enhance the quality of education in public schools.

\section{Reference}

[1] Lawrence Ingvarson,Elizabeth Kleinhenz, Jenny Wilkinson. Research on Performance Pay for Teachers[EB/OL].

[2] Benjamin Scafidi, David L. Sjoquist, Todd R.Stinebrickner. Race, Poverty, and Teacher Mobility[J].Economics of Education Review, 26(2007)145-159

http//www.dest.gov.au/NR/rdonlyres/D477C6A5-C8EF-4074-8619-FF43059445F8/252 08/ACER Performance Pay Paper.pdf.

[3] Education Labour Relations Council. Education Supply and Demand in the South African Public Education System [R]. Cape Town: HSRC Press, 2005: 29.

[4]https://docs.education.gov.au/system/files/doc/other/quality_teacher_program_funding_re cipient_guidelines_20112013.pdf

[5]https://docs.education.gov.au/system/files/doc/other/accessible_-_national_evaluation_for _the_low_ses_national_partnership_and_the_literacy_and_numeracy_national_partnership. pdf

[6] Department of Education, Employment and Workplace. Smarter Schools, 2008[DB/OL]. http//smarterschools.gov.au/Pages/default.aspx.

[7] Ministry of Education. 20 Hours ECE information and guidance for ECE services [Z]. Wellington: Ministry of Education, 2011.

[8] U.S Department of Education [EB/OL].

http://www2.ed.gov/programs/teacherqual/funding.html

[9] U.S Department of Education [EB/OL]. http://www2.ed.gov/programs/teacherqual/index.html

[10]U.S Department of Education [EB/OL]. http://www2.ed.gov/programs/heatqp/index.html

[11]U.S Department of Education [EB/OL]. http://www2.ed.gov/programs/teacherincentive/index.html 
[12]U.S Department of Education [EB/OL].

http //www2.ed.gov/programs/transitionteach/index.html

[13] U.S Department of Education, [EB/OL].

http://www2.ed.gov/programs/specedtq/funding.html

[14]U.S Department of Education, [EB/OL].

http://www2.ed.gov/programs/specedtq/funding.html 